川口駅周辺の住工混在地域の階層別空間利用 衣袋洋一、矢田部雅子、上島 進

\title{
Research and valuation on space use on each floor of buildings at mixed area with dweling and factory around Kawaguchi station
}

\author{
Youichi ITAI, Masako YATABE and Susumu KAMIJIMA
}

\begin{abstract}
Recent year, the aspect of the outer space around stations has been changing, because buildings that occupy a great deal of space have been constructed. While, as for the inner space of building, some users are made to exist each other on purpose as "the compound building of many functions".

By basing the monogragh "Research and valuation on space use on each floor of building with a method of three-dimensional mesh map" which was presented at GISA last year, we compare the data of space use around Kawaguchi station of twenty years before to the result of fact-finding inquiry of now. And then grasping the fact that the space use on each floor of buildings has changed according to the structual change of casting industry, at leash, we research why that has happend.
\end{abstract}

Keywords: 3 次元メッシュマップ、階層別空間利用、鋳物

\section{1.はじめに}

地域に根付き、地域の経済を支え、地域のコミュ ニティを成立させてきた地場産業は、今日様々な要 因のもと、その存立基盤を失い、衰退の方向へと 向っている。その結果、地域の土地、空間利用状況 の変化をもたらし、かつて地域がつくり出してきた 様々な「構造」及び地域としての「景観」に多いな る影響を与え、変貌することになった地域が多く見 られる。

本論文は、荒川を挟み東京に隣接する埼玉県南部 に位置し、かつてキューポラのある街として知ら れ、全国有数の鋳物産地であった川口市の川口駅東 口駅前地区を研究対象地域とする。

川口駅東口駅前地区の街区は、古くは農業基盤の 上に形成され、その後、鋳物工場及びそれを中心と して単位化された住宅群、付属する街路によって形 衣袋：テ330 埼玉県大宮市深作溜井原307 芝浦工業大学 システム工学部瑔境システム工学科 TEL 048-687-5835 Dept: of Archtecture and Environment System, Faculty of System Engineering, Shibaura Institute of Technology, 307 Fukasakutameihara, Omiya-shi, Saitama 330
成されるといった、いわば地場産業である鋳物を中 心に決定づけられていたといっても過言ではない。 つまりそれぞれの工場と住宅群、

それに張り巡らされたネットワーク網としての道 (鋳物原材料運般道路、参道、買い物通り、生活道 路）を1単位として有機的な街区構成がなされ、土 地、空間利用及び地域として「構造」、「景観」を 決定していたのである(佐藤)。しかし、川口駅東口 駅前地区は、今日の経済構造の変化、環境問題、地 価高騰及び㕍用の問題など様々な要因がもたらした 鋳物工業の不況によって、最盛期には 1000 件近く あった工場が、現在、わずか200件のみが操業する といった状況におち入り、その結果地域性が失わ れ、道や街区のかつての性格が薄れ、都心のベット タウン化に拍車をかけ、地域としての「景観」や 「構造」の急速な変化をとげた。

人口統計(三菱総合研究所)によれば、昭和 40 年 前後のマンション建設を契機に、現在の川口市の人 口は、当時の約二倍にあたる、4 4 万人を越えてい 
る。中でも、川口駅周辺のかつての鋳物工場集積地 带は、鋳物工場跡地の空間利用転換に伴う人口増 加、人口高密度化が目まぐるしい。

\section{2. 研究の目的}

川口駅前周辺鋳物工業衰退と市街地化の関係性 を、視覚的、3次元的に理解し、定性的分析を試み ることを本論文の目的とする。

具体的には、

1. 川口鋳物工場の分布を 20 年前と現在で比較 し、空間利用状況の変化を見る。

2. 重装備型工業（註 1 参照) (関、加藤)といわれ る鋳物工場の廃業または存続による工場周辺の空間 利用状況の変化の違いを見る。

以上（1）は時系列的な単純な利用状況の变化、

（2）は工場が周辺に及ほす環境の影響度による空 間利用状況の变化という 2 つの視点から視覚的、 3 次元的な定性的分析を試みる。

\section{3. 調査及びデータ処理}

3.1 対象地域

川口駅東口の半径約500メートルの範囲を対象地 域とする。この地域には、昭和 35 年から 36 年の 鋳物工業全盛期に鋳物生産で栄えた工場が多く存在 すると同時に、工場廃業による市街地化、住宅地化 が最も進んだ地域である。（図 1）

\section{2 調査方法とデータ作成システム}

現地調查をはじめる前に、1/2500の地形図もしく は1/1500の住宅地図をもとに、デジタイザーで敷地 及び建物形状を 2 次元データとして入力し、その データをもとに現地調査で階層の確認と階層毎の空 間利用の実態調查をし 2 次元データの修正と 3 次元 モデリングソフトを使用して 2 次元データを 3 次元 データに変換し、立方体を積み上げるかたちで 「キューブモデル」を作成する。

次に、昨年度本学会において発表した「3次元 メッシュマップ方法による階層別空間利用の実態調
査と評価」(衣袋、上島、関、1993)のシステムの一 部を以下の如く改定しデータ等を作成した(図 2)。

1）建物ごとの原点のもとにグリットを切っていた のを改め、川口駅東口に原点を設定し、地域全体を 同一メッシュ $(3.5 \mathrm{~m} \times 3.5 \mathrm{~m} \times 3.5 \mathrm{~m})$ で切り取り、同一 基準での全体分析を可能とした。

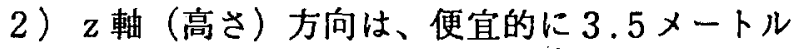
として数值としての意味合いを含んでいたが、今回 からは「階層」としての意味に重点を置く事にし た。

3）建物だけではなく、空地、道路等をも含んだ地 域全体に3次元メッシュをかけた。

4） CADのもつレイヤーの機能を活かし、昨年度 の階層別床利用用途別分類（13 分類）を更に細分 化し、200種類に再分類化した。

この改訂により、より明確で詳細な地域全体の空 間利用、土地利用状況を立体的に表示された分析用 のベースマップが可能となる。今回参照した全ての データは、平成 5 年 8 月 1 日現在のものである。

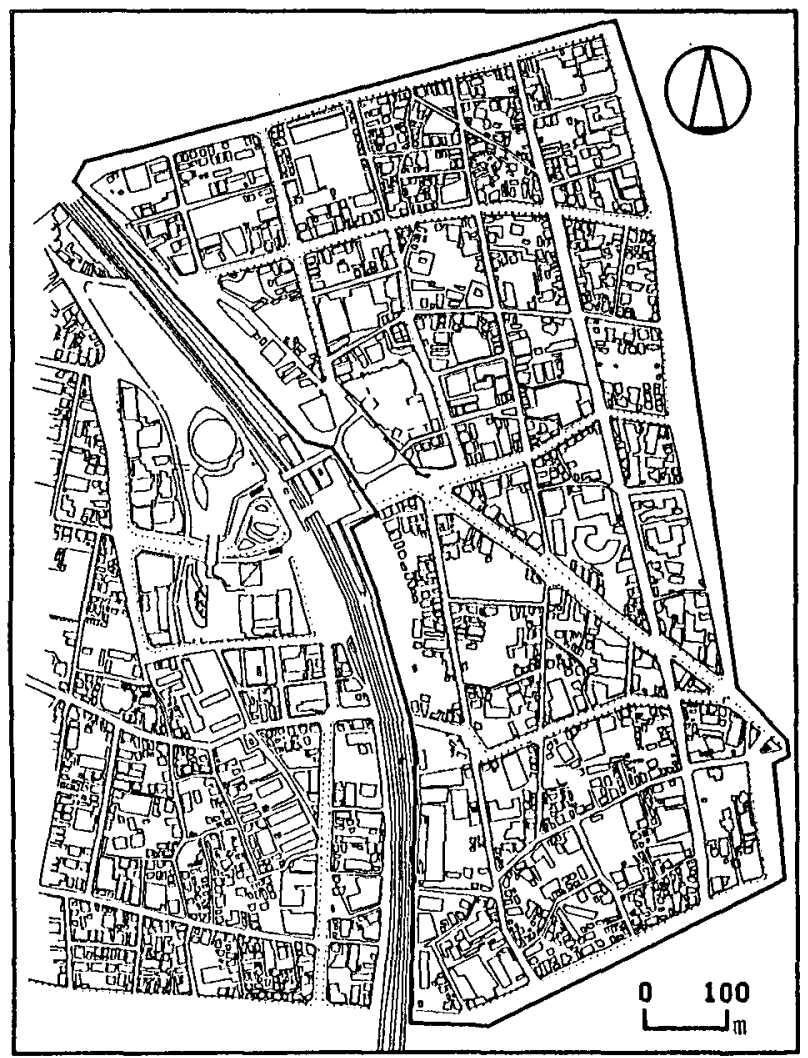

図 1. 川口駅東口 調查対象地域 


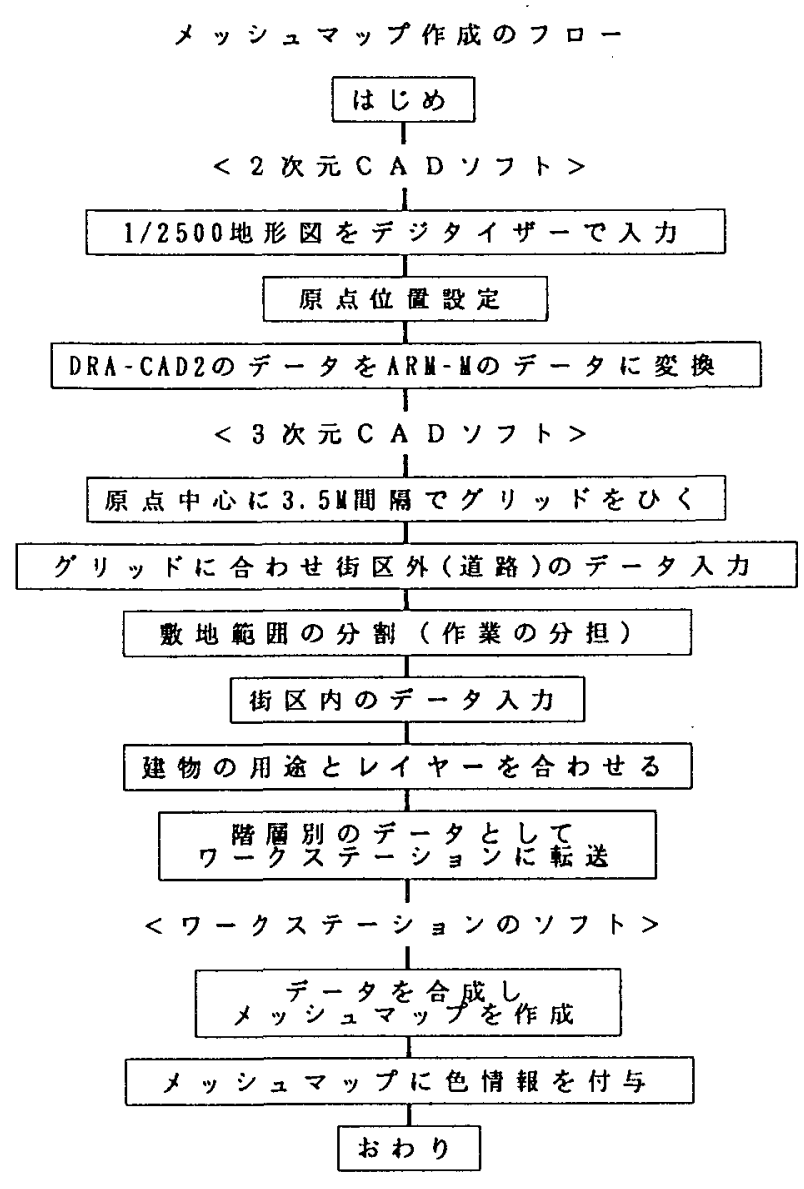

図 2. 作成システム図

\section{4. 分析}

4.1 内容

重装備型工業である鋳物工業が、周辺環境に与え る影響は大きい。川口鋳物工業衰退状況を把握し、 鋳物工場が殆ど廃業または移転した地域と、依然と して操業し続ける地域の空間利用状況を視覚的、3 次元的に表示させ、その違いを読み取る。

\section{2 調査・データ分析方法}

3.2のベースマップを目的に合わせて再統合す る。以下にその方法を示す。

（1） 20 年前の資料と現地調査をもとに、20年 前の空間利用に従ってベースマップを変更し、新し いデータを作成する。ただし、建物階数、建築面積 に不明確な点が多いこと、建物内における空間利用 状況が、現在に比べ単純化していたことから、便宜 上、全てを一層分の高さとし、建物部分と敷地部分 を同じ扱いとする。
（2）工場周辺の状況を、梘覚的により分かりやす く表示するために、表 1 の分類に従って、再統合す る。なお 20 年前の分類に扔いては（e）を（a） (b)（c）（d）にそれぞれ含むこととする。

表 1. 利用分類

\begin{tabular}{|c|c|c|c|}
\hline a & 工北系用途空闍利用 & 赤 & 面表示 \\
\hline b & 商莱・菜稀采用途空間利用 & 椂 & 面表示 \\
\hline$c$ & 住宅系用透空間利用 & 青 & 西表示 \\
\hline a & (a) (b) (c) 以外の用途空間利用 & 黒 & 腺表示 \\
\hline e & (a) (b) (c) (d) の教地部分 & 巵色 & 湶表示 \\
\hline 1 & 驻車、非䇶 & 粶 & 悢表示 \\
\hline 8 & 道路 & 白 & 線表示 \\
\hline
\end{tabular}

\section{3 結果}

対象地域の中に、鋳物工場存続状況、住工混在、 商業・業務分布状況の違いから、以下の二つのタイ プを挙げることができる。

\section{[タイプA]}

鋳物工場の殆どが住宅系空間利用に変化したタイプ

20 年前は、住宅系空間、商業・業務系空間、工 業系空間の混在した空間利用状況であった。工場系 空間は街区の中で集中し大きな面積を占め、商業系 空間は、街区の外郭部分において道に接する形で分 布している。この沿道に位置する商業系空間におい ては鋳物工場（工場系空間の大部分を占める）で生 産されたものが生活用品や雑貨として売られていた 事実から、生産者と消費者、及约両者をつなぐ販売 者が、一つの街区の中に共存していた事も読み取ら れる。つまり、異なる空間利用が混在しながら、そ の中で行われる生活活動はそれぞれ密接に関係を保 ち、鋳物を通じて物のサイクル、人と人との交流が 街区の中で成立していたのである。（写真 1）

20 年前の鋳物工場跡地は、重層化された住宅系 


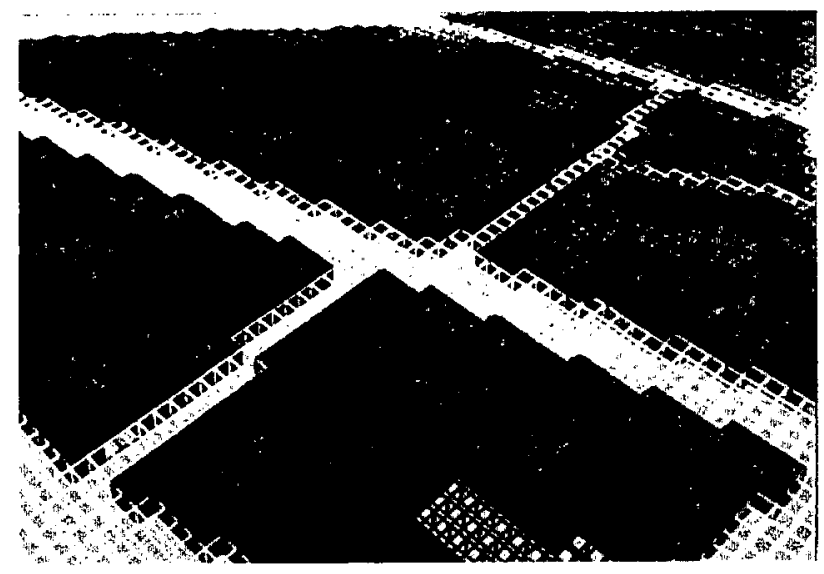

写真 1. [タイプA］20 年前の空間利用状況

用途空間利用へと変化した。その際、鋳物工場周辺 に存在した住宅や商店は、壊されるか、高層集合住 宅に取り込まれる。つまり、20年前の沿道に位置 する商業系空間は、 2 層もしくは 3 層の複合商業、

業務空間に変化するか、10層前後の集合住宅の低 層部に組み込まれている事をみることができる。さ らに鋳物工場跡地の一部は、駐車・駐輪場に用途変 化しているが、いずれ近いうちに、立体駐車場もし くは高層集合住宅などの土地生産性の高い空間利用 に用途変化されることが予想される。

今回 [タイプA］にとりあげた写真の地区におい ては、 20 年前 47 件だった住宅戸数が現在は 97 6件に増加し、その増加したほとんどは、集合住宅 として存在している。また商業、業務空間は、20 年前 104 件あった戸数の半分が廃業するかまたは 高層集合住宅に取り込まれる形で、現在は 158 件 に增加し、工業系空間は14 戸から2戸に減少して いる。（写真 2 )

商業、業務空間は高層集合住宅の一階、二階部分 に取り込まれる形で存在する。工業系空間が住宅系 空間に変化したことによる生活環境の変化は明らか である。

工業系空間が減少し、商業系空間が新しい形に生 まれ変わりながら増加した事実は、この地域の「住 まう」環境としての質が以前と変化したことと密接

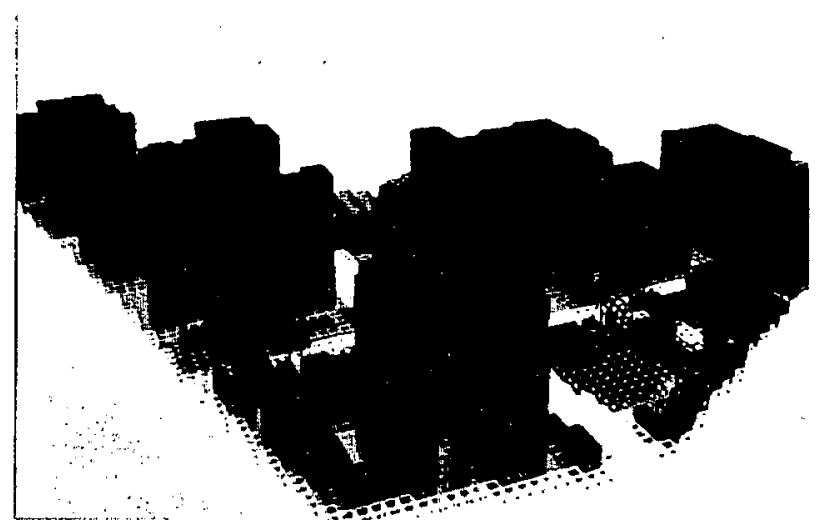

写真 2. [タイブA］現在の空間利用状況

に関係していると考えられる。

平屋建て商店街の並んだ沿道は、高層集合住宅の 連続する街並みへと変化し、視線の連続性の質、圧 迫度の違いから、20 年前と異なる景観となってい る。(写真 3 )

[タイプB]

鋳物工場が多く生き残るタイプ

20 年前の状況は [タイプA]に比べ工業系、住 宅系空間の占める割合が多いものの、[タイプA] と同じく住宅、工場、商店が混在している。（写真 4)
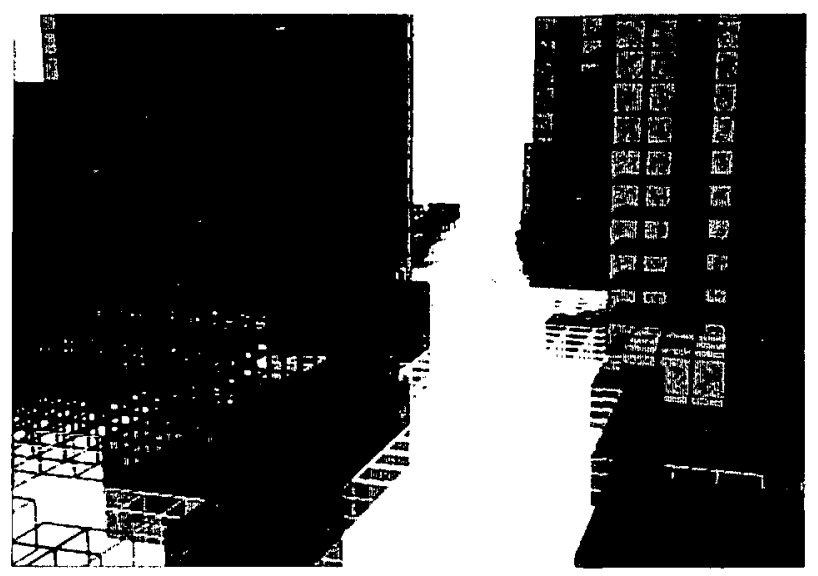

写真 3. [タイブA］現在の空間利用状況 
存続する鋳物工場、または廃業した「場所」（そ のほかの用途利用）が点在する住工混在の状況であ る。鋳物工場跡地は、駐車・駐輪場または集合住宅 に用途変化しているが、存続する鋳物工場も多く、 [タイプB] に比べて重層化（高層化）は進んでい ない。

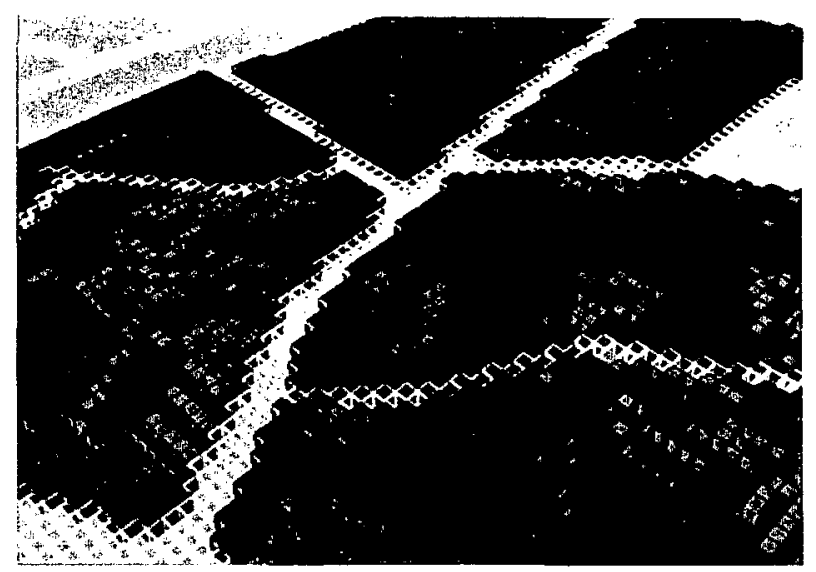

写真 4. [タイプB］ 20 年前の空間利用状況

[タイプB］にあげた写真の地域では、20年前 131 件あった住居が 344 件に増加してはいるも のの [タイプA］に比べその增加率は低い。また商 店が 26 件から 5 件に減少し集合住宅には商業空間 が取り込まれていないことから、このタイプでは時 間の経過と共に地域の住民が商業空間を地域外に求 める傾向にあることが読み取れる。鋳物生活用品が 日增しに減少し、20年前のような工場と住宅の密 接な関係が薄れた現在、鋳物工場がその「場所」に 存在する意味を持たなくなると同時に、住民の意識 の中で「住まう」環境としての価値基準が変化した ことも事実である。現在 [タイブB］において、鋳 物工場跡地が、多くの駐車場に変化し積極的に高層 住宅かしないのは、「住まう」環境としてこの地域 を不適ととる傾向が強くなってきていることとも影 響していると考えられる。（写真 5 ）

[タイプA]に比べ階層が低く抑えられている が、空間利用の複合化、多層化は殆ど進んでいな w。（写真 6$)$

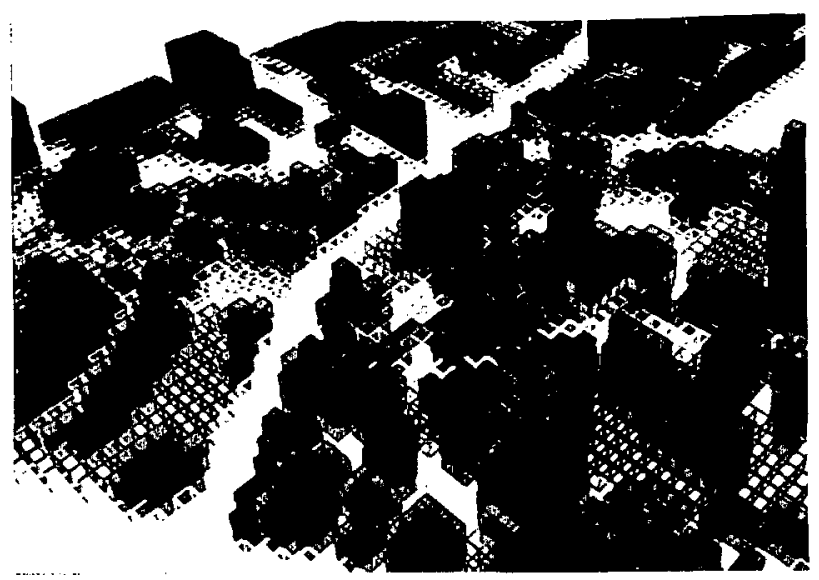

写真 5. [タイプB］現在の土地利用状況

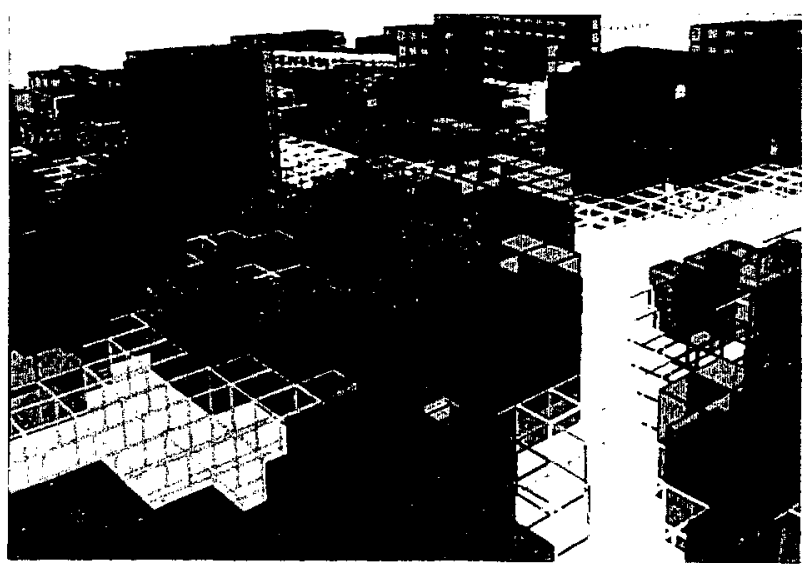

写真 6. [タイブB] 現在の土地利用状況

\section{5.まとめ}

ここ数年の間に、川口駅周辺の空間は、文化の情 報発信基地・リリアのある公共文化ゾーン（西口） と大手デパートや商店街のある商業ゾーン（東口） に変貌し、産業と文化が調和し高層集合住宅の建ち 並ぶ都市に変容した。しかしその一方で、かって川 口駅周辺に軒を連ねた鋳物工場や鋳物問屋、金物屋 は驚くべき速さで姿を消していったのである。

20 年前は駅周辺一体に分布した鋳物工場（写真 7）も現在は、 [タイプB] のような形で一部存在 する以外は、他の用途として空間利用されることと なった。（写真 8) 


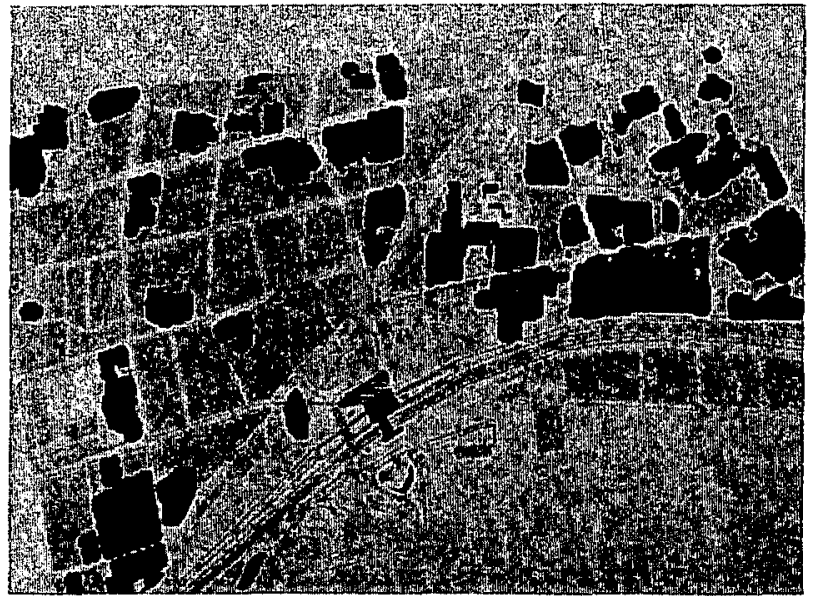

写真 7. 20 年前の鋳物工場の分布状況

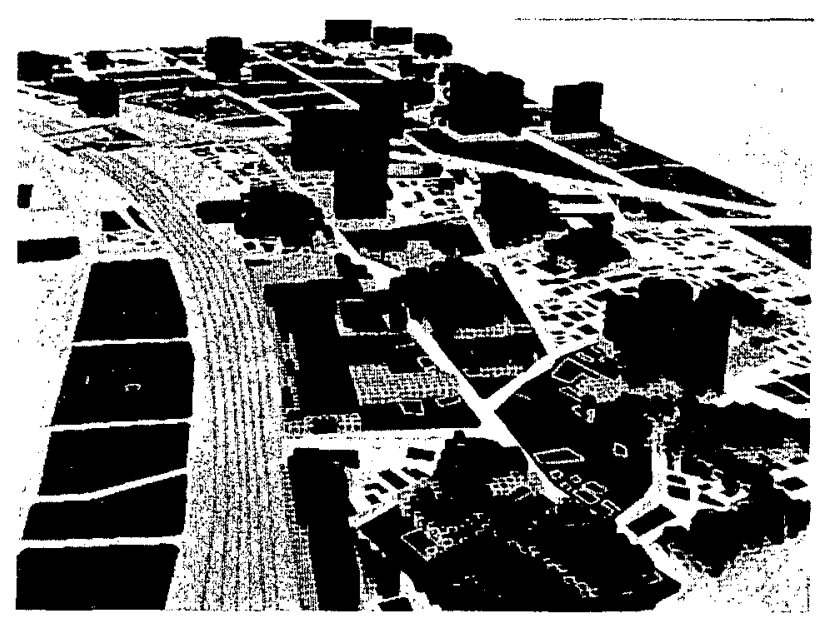

写真 8. 鋳物工場空間利用変化状況

一般的に各地域には市街地化を促すそれぞれの要 因がある。川口駅東口に扔いては、かっての鋳物工 場の存在がそれに当たり、鋳物工場の衰退を抜きに して、市街地化や住宅地化の変化は考えられないの である。

さらに言えることは $4-3$ の結果からわかるよう に、鋳物工場の衰退が、周囲住環境の向上と綿密に 関係しているということである。

工場衰退と住宅地化は、両者が「原因」と「結 果」の関係を交互に繰り返しながら市街地化に拍車 をかけることとなり、この変化と共に、住民の意識 の中にも住まう環境としての価值基準の変化がみら れる。以前、住民は街区内で情報やものを取得して
いたが、現在ではその多くを東京の中に求めるよう になり、住民は街区内や地域内で完結された生活の システムを要求もしなければ必要ともされない状況 となってしまったのである。

人々の関心は、住宅の㐮通りよりも駅へ通じるア クセス道路に傾き、景観より個人的な欲望のための 眺望や高級感を優先させた強引な計画は、完全に

「污い物」「古い物」を排除してしまった今、川口 のラベルをはることのできるエレメントは少ない。

ここで [タイプA］［タイプB]へと分化した経 過をまとめる。

[ 20 年前 $]$

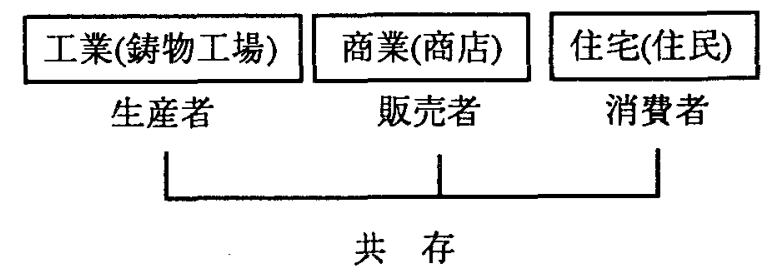

[現在\}

[タイプA]

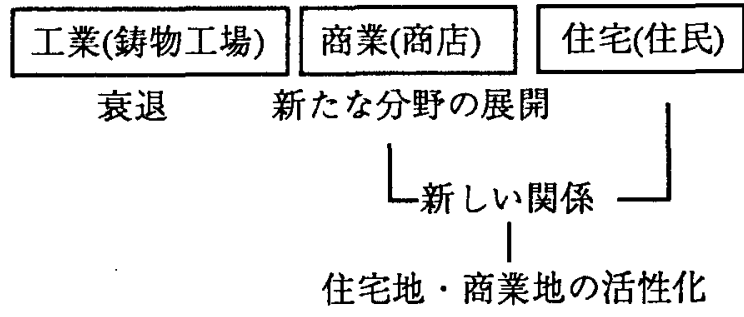

[タイプB]

\begin{tabular}{|c|c|c|}
\hline 工業(鋳物工場) & 商業(商店) & 住宅(住民) \\
\hline \multirow[t]{4}{*}{ 存続 } & \multicolumn{2}{|l|}{ 衰退 } \\
\hline & \multirow{2}{*}{\multicolumn{2}{|c|}{$\begin{array}{c}\text { L関係が薄れる- } \\
\text { 工場敵対意識 }\end{array}$}} \\
\hline & & \\
\hline & \multicolumn{2}{|c|}{ 環境悪イメージ } \\
\hline
\end{tabular}

6. おわりに

今回の分析をもとに、今後は、川口鋳物工業を維 持、存続、発展させるための梘点に立ち、鋳物工場 
を残すための、残れるための環境指数を出すと同時 に、住居と共存できる地域の再構成の分析のため に、3次元メッシュマップを活用していくこととす る。

今日までの G I S の 2 次元メッシュマップ法は、 土地利用の状況等、都市計画レベルでの比較的広域 における都市情報の数値による統計的処理が主なる 目的であり、広域、スケールの大きな「都市環境情 報地図」であった。しかし、今日、多くの市街地周 辺地域においての空間利用は複合化、多層化してい る状況にあって、数值、色付けされた 2 次的平面情 報では地域の棬造、特徴を理解することは困難な状 況であり、地域を理解する新たな手法が必要になっ てきている。今回使用した「3次元メッシュマップ 法」は、単に土地、床利用を 3 次元的に表現するの みではなく、土地、床を 3 次元の基準単位（3.5 X $3.5 \times 3.5 \mathrm{~m}$ ) の「色情報」をもった格子の集積 二「都市環境情報地図」を作成するシステムであ る。

集積された「色情報」としての「地図」が換気す るイメージは、都市計画などの専門家は言うに及ば ず、特に定性的な評価を主にする一般市民のレベル で地域に密着した「都市環境情報地図」、コミュニ ティを活性化させる街づくり情報図として有効なシ ステム、表現方法であると考える。

と同時、「3次元メッシュマップ法」を土地、空 間利用分析の手法としてより一層有効なものとする ためには、定性的な評価のためのベースマップとし ての3次元的な「色情報」のみに止まらず、「色情 報」の「数值情報」への変換及びその相似性の確保 への取り組みが、今後我々が解決すべき課題であ る。

（註 1）(関、加藤)は、機械金属工業を加工機能別 に、製品開発型企業、機械加工型企業、重装備型企 業、周辺的企業に分類している。

\section{参考文献}

衣袋洋一, 上島進, 関益巳 (1993) 3 次元メッシュマッ プ方法による階層別空間利用に関する実態調査 研究とその評価, [GIS-理論と応用], 1, 1-10. 佐藤滋, 住区環境研究会 [現代に生きるまち], 彰国社 関满博, 加藤秀雄 [現代日本の中小機械工業ーナショ ナルテクノポリスの形成」,新評論

三菱総合研究所,川口市, 「川口市の鋳物・機械工業 の総合振興ビジョンに関する調査研究」 


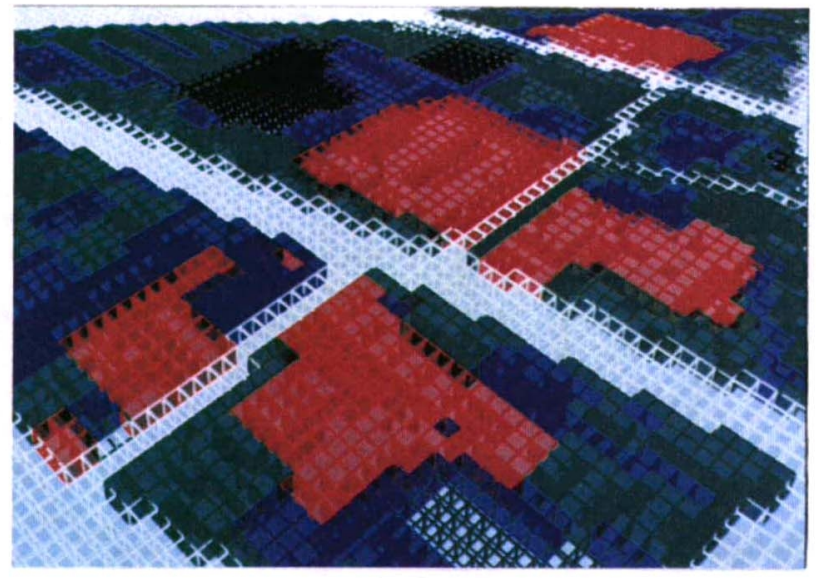

写真 1. [タイプA］20 年前の空間利用状況
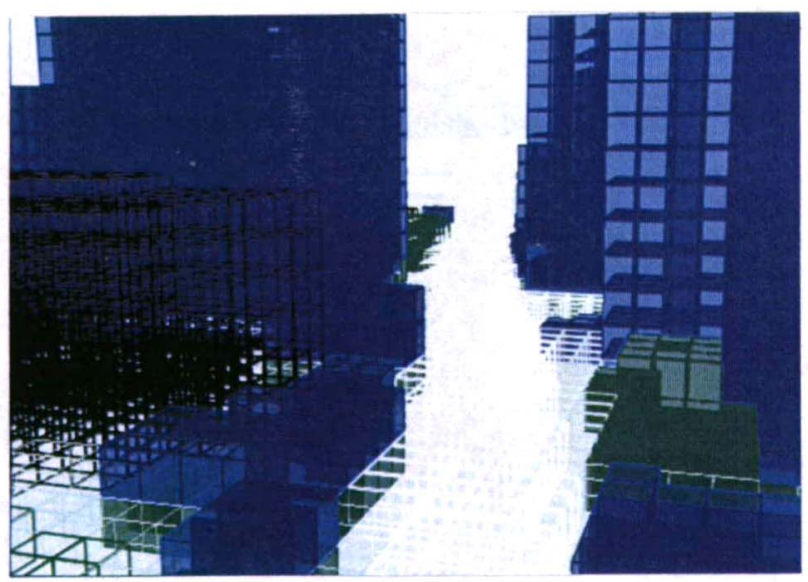

写真 3. [タイプA］現在の空間利用状況

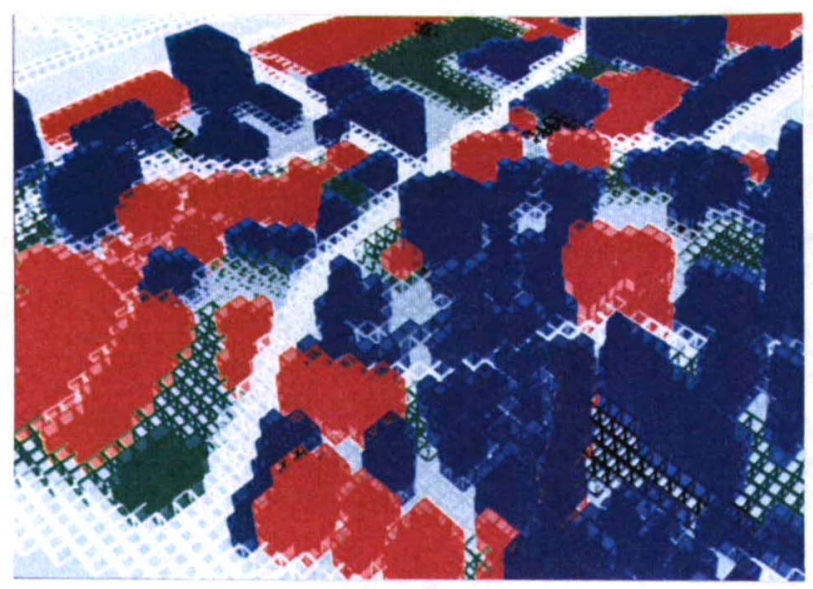

写真 5. [タイプB］現在の土地利用状況

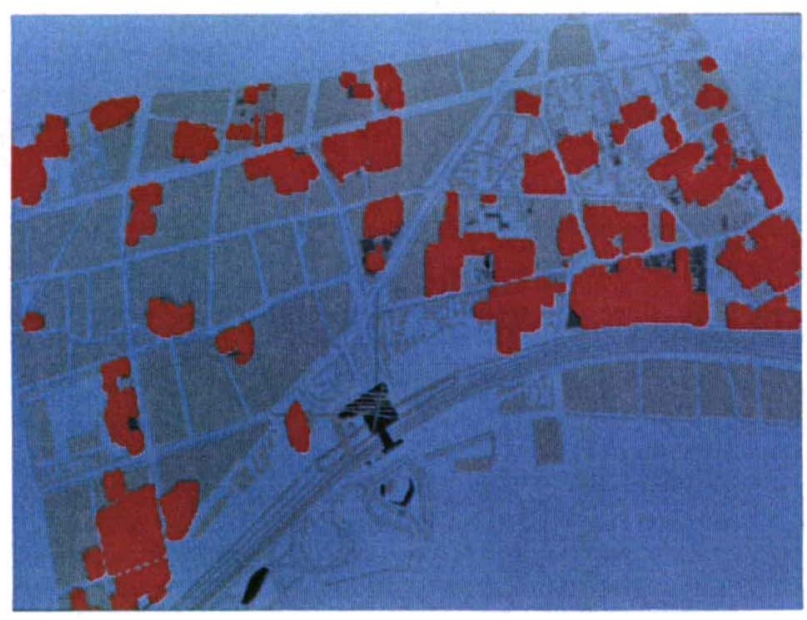

写真 7. 20 年前の鋳物工場の分布状況

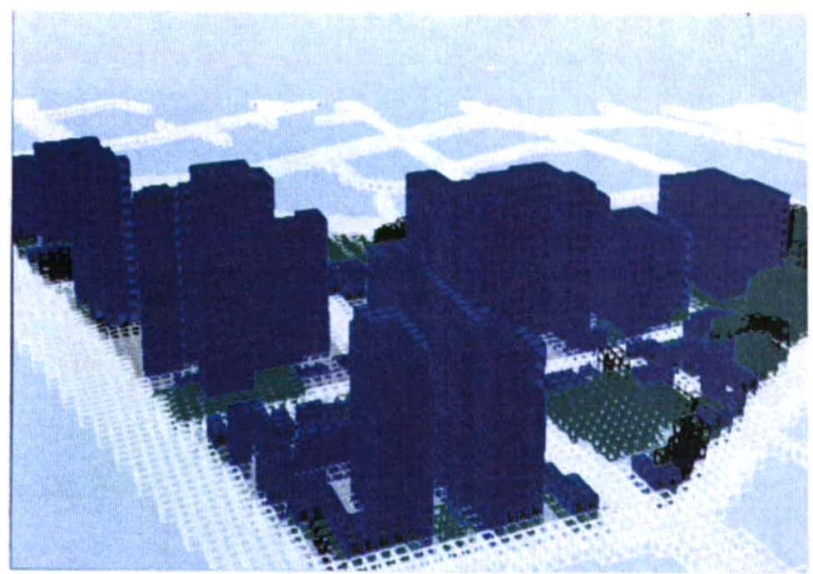

写真 2.［タイプA］現在の空間利用状況

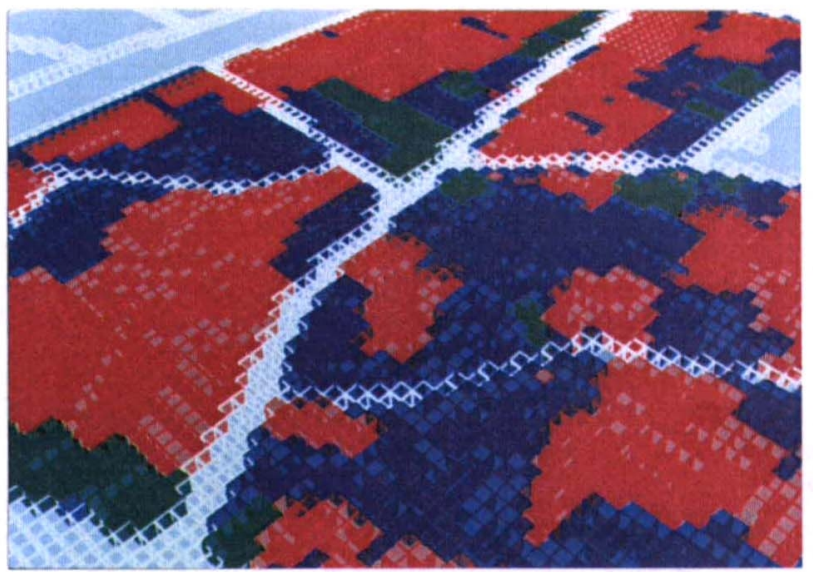

写真 4. [タイプB ］ 20 年前の空間利用状況

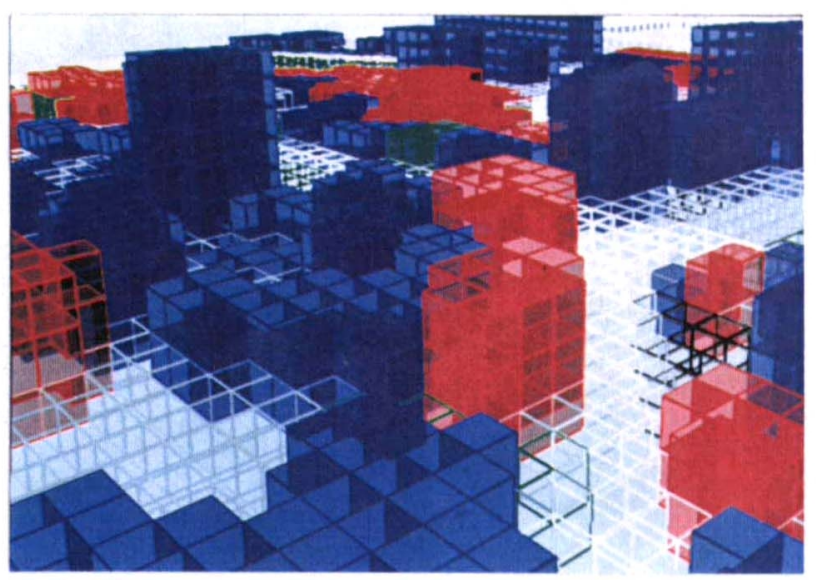

写真 6. [タイプB］現在の土地利用状況

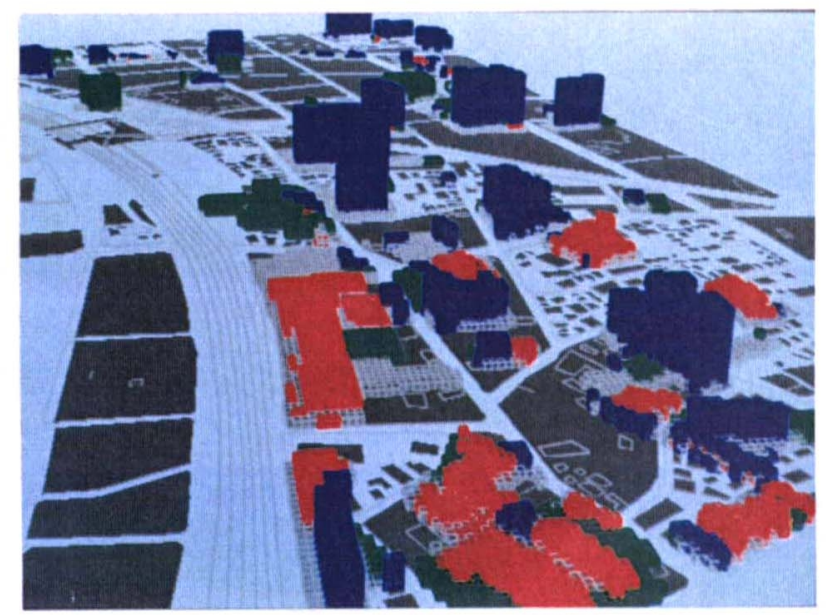

写真 8. 鋳物工場空間利用変化状況 